\title{
Pteroylglutamic (folic) acid in different feedstuffs: the pteroylglutamate content and an attempt to measure the bioavailability in pigs
}

\author{
BY J. JACQUES MATTE AND CHRISTIANE L. GIRARD \\ Station de recherches, Agriculture Canada, Lennoxville, Québec, Canada, JIM $1 Z 3$
}

(Received 21 February 1994 - Revised 30 March 1994 - Accepted 12 April 1994)

\begin{abstract}
Sixty piglets selected after weaning at 4 weeks of age were assigned to five replicates of twelve animals each. In each of these replicates the postprandial variations in serum pteroylglutamate after the ingestion of twelve sources of dietary pteroylglutamic acid were recorded twice weekly at 10 and 16 weeks of age. In six of these sources of pteroylglutamic acid the chemically pure form of the vitamin was incorporated into a semi-purified diet at concentrations varying between 0 and $1.0 \mathrm{mg} / \mathrm{kg}$. The six other sources were provided by a soya-bean meal, rapeseed meal, maize, barley, wheat, and a commercial vitamin premix. The concentrations of pteroylglutamates measured by radioimmunoassay in the different feedstuffs were, in most cases, far from the values reported in the literature, except for maize. Indeed, while total pteroylglutamates in barley, wheat and rapeseed meal were lower by $35-56 \%, 17-50 \%$ and $60 \%$ respectively compared with references values, the corresponding values for soya-bean meal ranged from one third to twice as much. The area under the curve (AUC) of the pre- and postprandial $(1,2,3,5$ and $7 \mathrm{~h}$ ) serum pteroylglutamate following ingestion of increasing levels of chemically pure pteroylmonoglutamic acid was used to derive a regression for the $100 \%$ bioavailability of dietary pteroylglutamic acid. The corresponding AUC for the feedstuff sources of pteroylglutamates were used in the regression to determine the proportion of bioavailable pteroylglutamates out of total pteroylglutamates measured in these ingredients. No relationship $(P>0.66)$ was found between the level of chemically pure dietary pteroylmonoglutamic acid and the postprandial AUC. In fact, there was no significant $(P>0.11)$ increase in the postprandial concentration of serum pteroylglutamate for any of the pteroylglutamate sources used except for wheat. Moreover, values tended $(P<0.08)$ to be lower at 5 and $7 \mathrm{~h}$ postfeeding except for wheat and barley. It was hypothesized that this decrease is probably linked to the postfeeding variation in bile secretion which drains considerable amounts of circulatory pteroylglutamates. The results of the present experiment indicate that further research on analytical procedure is needed in order to provide a reliable method for measuring concentrations of pteroylglutamic acid in different sources of a given feedstuff used in pig feeding. In addition to this analytical concern, the measurement of the proportion of bioavailable pteroylglutamic acid in feedstuffs for pigs using postprandial variations of serum pteroylglutamates appears to be technically hazardous.
\end{abstract}

Pig: Feedstuffs: Pteroylglutamic acid: Bioavailability: Serum pteroylglutamate

During the last few years it has become common to incorporate supplements of pteroylglutamic (folic) acid into pig diets because of its effects on animal productivity (Matte et al. 1984b, 1992; Lindemann \& Kornegay, 1986, 1989; Kovčin et al. 1988; Thaler et al. 1989; Friendship \& Wilson, 1991). Since the requirement is still under debate, the amount of pteroylglutamic acid added may vary widely among sources of recommendations. However, it can represent more than $50 \%$ of the amount provided naturally by the feedstuffs. The feedstuffs used generally as protein sources such as soya-bean, rapeseed, and lucerne (Medicago sativa) meal are known to be relatively rich in pteroylglutamic acid (approximately $1.5 \mathrm{mg} / \mathrm{kg}$ ) while those used mainly as energy sources, such as cereals, 
provide low amounts of pteroylglutamic acid (approximately $0.6 \mathrm{mg} / \mathrm{kg}$; Institut National de la Recherche Agronomique (INRA), 1984; Alimentation Équilibrée Commentry (AEC), 1987; National Research Council (NRC), 1988). Although used widely to calculate dietary pteroylglutamic acid provided by the ingredients in a balanced diet, these dietary concentrations of pteroylglutamic acid are not necessarily a reliable indication of the proportion of the vitamin bioavailable for the animal.

Pteroylglutamic acid in feedstuffs is present as various forms of pteroylpolyglutamates

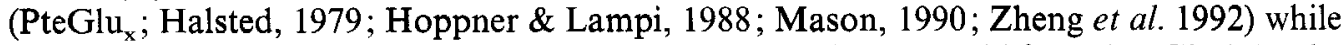
the vitamin supplements contain essentially the pteroylglutamic acid form $\left(\mathrm{PteGlu}_{1}\right)$. In the small intestine of the pig, dietary PteGlu are hydrolysed to PteGlu $_{1}$ by the enzyme polyglutamate hydrolase (EC 3.4.22.12) also called conjugase (Chandler et al. 1986; Buffington et al. 1987; Halsted, 1989). The PteGlu ${ }_{1}$ is absorbed more rapidly than the PteGlu $_{\mathrm{x}}$. However, the overall percentage of absorption is considered to be either similar (Halsted, 1979) or reduced by the polyglutamate forms (Gregory et al. 1991). The age (Shojania \& Hornady, 1970; Said et al. 1986) as well as the nutritional status (Farrar et al. 1989) of the animal are also involved in the absorptive capacity for pteroylglutamic acid.

Two main types of technique have been used to measure the bioavailability of B vitamins in feed. The first, measurement of ileal digestibility in growing pigs, was used for biotin (Mosenthin et al. 1990). Although attractive, this technique is unlikely to measure accurately the bioavailability of dietary pteroylglutamates due to the artifact related to the endogenous pteroylglutamates provided by the entero-hepatic cycle (Lavoie \& Cooper, 1974). The most commonly used bioavailability assay, reviewed by Keagy (1990), consists of the measurement of the compensatory growth (Clifford et al. 1993) or repletion of hepatic reserves (Hoppner \& Lampi, 1986, 1988; Babu \& Lakshmaiah, 1987; Farrar \& Blair, 1989; Gee et al. 1989a) in pteroylglutamate-depleted animals following intakes of different feedstuff sources of pteroylglutamate. This response is compared with that for the chemically pure nutrient which is assumed to be $100 \%$ available. Some doubts have been raised about the accuracy of such techniques (Hoppner \& Lampi, 1986); standardized procedures are necessary for the reliability of the measured responses (Clifford et al. 1993).

The use of serum pteroylglutamate as a response criterion for pteroylglutamate bioavailability is also described in different studies (Perry \& Chanarin, 1968; Shojania \& Hornady, 1970; Hages et al. 1987; Keagy et al. 1988; Gee et al. 1989a, b; Swiatlo et al. 1990). Since serum pteroylglutamate is considered to be a precise index of the pteroylglutamate status in humans (Gee et al. 1989 a, b) and in pigs (Matte et al. 1984a), it was chosen as a response criterion in the present experiment.

\section{MATERIALS AND METHODS}

\section{Animals and treatments}

After weaning at 4 weeks of age, sixty piglets were assigned, according to weight and date of weaning, to five replicates of twelve animals each. In each of these replicates, the postprandial variations in serum pteroylglutamate after the ingestion of twelve sources of dietary pteroylglutamic acid were recorded twice weekly at 10 and 16 weeks of age.

During the first 4 weeks of the experiment the piglets were raised in groups of six animals or less on concrete flooring in pens of $1.5 \times 3.5 \mathrm{~m}$; room temperature was adjusted to $20^{\circ}$ and natural lighting was provided throughout the experimental period. Within each pen, pigs were given ad lib. access to water and to the starting diet described in Table 1. During this period, $1 \mathrm{ml}$ of a solution containing $20 \mathrm{mg}$ pteroylmonoglutamic acid $/ \mathrm{ml}$ $\left(\mathrm{C}_{19} \mathrm{H}_{19} \mathrm{~N}_{7} \mathrm{O}_{6}\right.$, molecular weight $441.4 ; 101725$, ICN Canada Ltd, Montréal, Québec, Canada) was injected intramuscularly twice weekly. These injections were used to saturate 
Table 1. Composition $(\mathrm{g} / \mathrm{kg})$ of the experimental diets

\begin{tabular}{|c|c|c|c|}
\hline \multirow[b]{2}{*}{ Ingredients } & \multicolumn{3}{|c|}{ Diets } \\
\hline & Starting & Growing & Basal semi-purified \\
\hline Maize & 617 & 652 & - \\
\hline Wheat bran & - & 100 & - \\
\hline Soya-bean meal (48\%) & 300 & 193 & - \\
\hline Animal fat & 29 & 10 & - \\
\hline Maize starch & - & - & 630 \\
\hline Casein (vitamin-free) & - & - & 150 \\
\hline Sucrose & - & - & 100 \\
\hline Cellulose & 一 & - & 60 \\
\hline Limestone & 21 & 18 & 7 \\
\hline Dicalcium phosphate & 21 & 18 & 42 \\
\hline Salt & 6 & 3 & 5 \\
\hline \multicolumn{4}{|l|}{ Premixes } \\
\hline Minerals* & 1 & 1 & 1 \\
\hline Vitamins $\dagger$ & 5 & 5 & 5 \\
\hline
\end{tabular}

* Provided (/kg diet): Mn $30 \mathrm{mg}, \mathrm{Zn} 100 \mathrm{mg}, \mathrm{Fe} 100 \mathrm{mg}, \mathrm{Cu} 25 \mathrm{mg}$, Co $300 \mu \mathrm{g}, \mathrm{I} 300 \mu \mathrm{g}$, and Se $300 \mu \mathrm{g}$.

+ Provided ( $/ \mathrm{kg}$ diet): retinol $3000 \mu \mathrm{g}$, cholecalciferol $50 \mathrm{mg}, \alpha$-tocopherol $34 \mathrm{mg}$, menadione $2 \cdot 2 \mathrm{mg}$, thiamin $3 \mathrm{mg}$, riboflavin $6 \mathrm{mg}$, nicotinic acid $30 \mathrm{mg}$, pantothenic acid $16 \mathrm{mg}$, pyridoxine $4 \mathrm{mg}$, biotin $300 \mu \mathrm{g}$, cyanocobalamin $40 \mu \mathrm{g}$ and choline $400 \mathrm{mg}$.

the tissues of the pigs with pteroylglutamates (Matte et al. 1990). Such a prerequisite was necessary in order to prevent any artifact due to rapid tissue uptake by the animals after ingestion of the dietary sources of pteroylglutamic acid studied. At 1 week before the first studied age (10 weeks), the animals $(16 \cdot 2$ (SE $0 \cdot 2) \mathrm{kg}$ ) were moved into individual pens and fed on a semi-purified diet (Table 1) without added pteroylglutamic acid. The daily allowance was divided into two meals of $450 \mathrm{~g}$ each, which were distributed at 08.30 and 16.30 hours. At 10 weeks of age one pig within each replicate received one of the twelve studied sources of pteroylglutamic acid. These twelve sources and the different procedures for their respective incorporation into the basal semi-purified diet are described in Table 2 . Blood samples for serum pteroylglutamate determinations were withdrawn by jugular venepuncture immediately before and at $1,2,3,5$, and $7 \mathrm{~h}$ after the morning meal (S1) containing the source of pteroylglutamic acid tested. After $2 \mathrm{~d}$, the procedure described for S1 was repeated with the same animals receiving the same source of pteroylglutamic acid (S2). During that week, the intramuscular injections of pteroylglutamic acid were given at least $36 \mathrm{~h}$ before sampling.

On the day following $\mathrm{S} 2$, the animals were returned in groups of six or less to their original pen and had ad lib. access to the growing diet described in Table 1 for the next 4 weeks. They were injected again twice weekly with $2 \mathrm{ml}$ of a solution containing $20 \mathrm{mg}$ pteroylmonoglutamic acid $/ \mathrm{ml}$. The procedure used at 10 weeks of age was repeated at 16 weeks of age. At 15 weeks of age, the animals $(46.7$ ( $\mathrm{SE} 0.7) \mathrm{kg}$ ) were moved again into individual pens and given the same semi-purified diet as previously described. The daily allowance was divided into two meals of $900 \mathrm{~g}$ each, which were distributed at 08.30 and 16.30 hours. On the following week, a first (G1) and a second (G2) meal containing the source of pteroylglutamic acid tested were given to the same animals as previously described for S1 and S2 respectively. Again during that week the intramuscular injections of pteroylmonoglutamic acid were given at least $36 \mathrm{~h}$ before sampling. The animals were cared for according to the recommended code of practice of Agriculture Canada (1984). 
Table 2. Description of the twelve test meals used to determine the postprandial area under the serum pteroylglutamate curve for six levels of chemically pure pteroylmonoglutamic acid (standard curve) and for different feedstuffs which are mainly protein, energy or pteroylglutamic acid sources

\begin{tabular}{|c|c|}
\hline Test meal & $\begin{array}{l}\text { Replacement procedure of } 25 \% \text { of the basal semi-purified } \\
\text { diet by known or unknown sources of pteroylglutamic } \\
\text { acid (per kg) }\end{array}$ \\
\hline \multicolumn{2}{|c|}{$\begin{array}{l}\text { Standard curve } \\
\text { (addition of pteroylmonoglutamic acid, } \\
\mathrm{mg} / \mathrm{kg} \text { semi-purified diet) }\end{array}$} \\
\hline 0 & No replacement \\
\hline 0.05 & $\begin{array}{l}250 \mathrm{~g} \text { of the maize starch was replaced by } 250 \mathrm{~g} \text { of a maize } \\
\text { starch supplemented with } 0.2 \mathrm{mg} \text { pteroylmonoglutamic acid } / \mathrm{kg}\end{array}$ \\
\hline $0 \cdot 10$ & $\begin{array}{l}250 \mathrm{~g} \text { of the maize starch was replaced by } 250 \mathrm{~g} \text { of a maize } \\
\text { starch supplemented with } 0.4 \mathrm{mg} \text { pteroylmonoglutamic acid } / \mathrm{kg}\end{array}$ \\
\hline $0 \cdot 15$ & $\begin{array}{l}250 \mathrm{~g} \text { of the maize starch was replaced by } 250 \mathrm{~g} \text { of a maize } \\
\text { starch supplemented with } 0.6 \mathrm{mg} \text { pteroylmonoglutamic acid } / \mathrm{kg}\end{array}$ \\
\hline $0 \cdot 20$ & $\begin{array}{l}250 \mathrm{~g} \text { of the maize starch was replaced by } 250 \mathrm{~g} \text { of a maize } \\
\text { starch supplemented with } 0.8 \mathrm{mg} \text { pteroylmonoglutamic acid } / \mathrm{kg}\end{array}$ \\
\hline $0 \cdot 40$ & $\begin{array}{l}250 \mathrm{~g} \text { of the maize starch was replaced by } 250 \mathrm{~g} \text { of a maize } \\
\text { starch supplemented with } 1.6 \mathrm{mg} \text { pteroylmonoglutamic acid } / \mathrm{kg}\end{array}$ \\
\hline \multicolumn{2}{|c|}{ Feedstuffs (dietary protein sources) } \\
\hline Soya-bean meal & $\begin{array}{l}125 \mathrm{~g} \text { of the maize starch and } 125 \mathrm{~g} \text { of the casein (vitamin } \\
\text { free) were replaced by } 250 \mathrm{~g} \text { soya-bean meal }(48 \%)\end{array}$ \\
\hline Rapeseed meal & $\begin{array}{l}150 \mathrm{~g} \text { of the maize starch and } 100 \mathrm{~g} \text { of the casein (vitamin } \\
\text { free) were replaced by } 250 \mathrm{~g} \text { rapeseed meal }\end{array}$ \\
\hline \multicolumn{2}{|c|}{ Feedstuffs (dietary energy sources) } \\
\hline Maize & $\begin{array}{l}200 \mathrm{~g} \text { of the maize starch and } 50 \mathrm{~g} \text { of the casein (vitamin } \\
\text { free) were replaced by } 250 \mathrm{~g} \text { maize }\end{array}$ \\
\hline Barley & $\begin{array}{l}150 \mathrm{~g} \text { of the maize starch and } 100 \mathrm{~g} \text { of the casein (vitamin } \\
\text { free) were replaced by } 250 \mathrm{~g} \text { barley }\end{array}$ \\
\hline Wheat & $\begin{array}{l}125 \mathrm{~g} \text { of the maize starch and } 125 \mathrm{~g} \text { of the casein (vitamin } \\
\text { free) were replaced by } 250 \mathrm{~g} \text { wheat }\end{array}$ \\
\hline \multicolumn{2}{|c|}{ Dietary vitamin source } \\
\hline Vitamin premix* & $\begin{array}{l}250 \mathrm{~g} \text { of the maize starch was replaced by } 250 \mathrm{~g} \text { of a maize } \\
\text { starch supplemented with } 5 \mathrm{~g} \text { Optiblend vitamin } / \mathrm{kg}\end{array}$ \\
\hline
\end{tabular}

* Optiblend vitamin ${ }^{\circledR}$, Hoffman-La Roche Canada Ltd, Mississauga, Ontario, Canada.

Pteroylglutamate determinations in serum and feedstuffs

Concentrations of serum pteroylglutamate were measured by the validated procedure described by Matte \& Girard (1989) and Tremblay et al. (1986).

Dietary pteroylglutamates were analysed in duplicate on three hydrolysates of the same sample with commercial radioassay kits using $\left[{ }^{125} I\right]$ pteroylmonoglutamic acid as described by Matte et al. (1990). Preparation of samples before the assay was done according to a method adapted from Cerna \& Kas (1983). In a conical tube of $50 \mathrm{ml}$ capacity, $0 \cdot 1 \mathrm{~g}$ feed was mixed with $12 \mathrm{ml} \mathrm{McIlvain} \mathrm{buffer} \mathrm{(for} 100 \mathrm{ml}: 28.4 \mathrm{~g} \mathrm{Na}_{2} \mathrm{HPO}_{4}, 50 \mathrm{mg}$ ascorbic acid, add distilled water, adjust $\mathrm{pH}$ to 4.6 with $3.3 \mathrm{M}-\mathrm{NaOH}$ and complete with distilled water up to $100 \mathrm{ml}$ ) and autoclaved for $10 \mathrm{~min}$ at $121^{\circ}$. The $\mathrm{pH}$ was adjusted to 7.0 with $3.3 \mathrm{M}-\mathrm{NaOH}$ and the volume completed to $20 \mathrm{ml}$ with distilled water. The solution was vortexed and then centrifuged at $3000 \mathrm{~g}$ for $10 \mathrm{~min}$. The supernatant was used for pteroylglutamate determination. The effect of chicken pancreas conjugase (transformation of $\mathrm{PteGlu}_{\mathrm{x}}$ to PteGlu $_{1}$ ) on concentrations of pteroylglutamates was tested using the method described by Cerna \& Kas (1983). No effect of conjugase was noted on concentrations of dietary 
pteroylglutamates and, subsequently, all assays were run without pretreatment with conjugase. The results seem to confirm previous observations (Rothenberg et al. 1974; Schreiber \& Waxman, 1974) on the versatility of the radioassay technique for both PteGlu

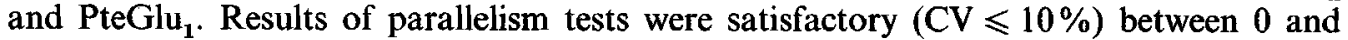
$5 \mathrm{mg} / \mathrm{kg}$ and the inter-assay coefficient of variation was $9.1 \%$. Recovery tests from a simulated mixing in the laboratory gave a mean of $94 \cdot 2 \%$.

\section{Statistical analysis}

For each age, the pooled (S1 and S2, G1 and G2) preprandial concentrations of serum pteroylglutamate were compared with their corresponding postprandial values using a $t$ test. Moreover, for each age the pooled (S1 and S2, G1 and G2) area under the postprandial curve (AUC) of serum pteroylglutamate was used as a dependent variable and analysed as a randomized block design with the preprandial concentration of serum pteroylglutamate as a covariate and the six levels of chemically pure pteroylmonoglutamic acid (standard curve) added in the semi-purified diets (Table 2) as the independent variables. The regression derived from this analysis was planned to be used as the standard curve for the $100 \%$ bioavailability of dietary pteroylglutamic acid.

The pooled (S1 and S2, G1 and G2) AUC of serum pteroylglutamates in pigs receiving the feedstuffs and the vitamin premix was planned to be used in the regression derived from the standard curve to determine the proportion of bioavailable pteroylglutamic acid compared with the analytical content of pteroylglutamic acid in the feedstuff. However, since no significant regression was found in the standard curve, the AUC in pigs receiving the feedstuffs were used as dependent variable and analysed as a randomized block design by the GLM procedure of Statistical Analysis Systems (1990) with the preprandial concentration of serum pteroylglutamate as a covariate and the six feedstuff sources of pteroylglutamic acid incorporated into the semi-purified diets (Table 2) as the independent variables.

Least square means among treatments from dependent variables were compared using Duncan's multiple range test at $P \leqslant 0.05$.

\section{RESULTS AND DISCUSSION}

\section{Analytical values}

The pteroylglutamate contents reported in Table 3 were in most cases far from the values usually reported in the literature. The maize was the only ingredient where the different sources of information agreed approximately among themselves and with the present results (Table 4). In the other cereals, the concentrations in the present experiment were lower by $35-56 \%$ in barley and by $17-50 \%$ in wheat when comparisons were made with INRA (1984), AEC (1987), NRC (1988) and McDowell (1989). The values reported by Aitken \& Hankin (1970) ranged between 0.37 and $0.56 \mathrm{mg} / \mathrm{kg}$ for wheat and 0.45 and $0.67 \mathrm{mg} / \mathrm{kg}$ for barley. The differences reported for the protein sources were much more considerable. Indeed, the pteroylglutamate content of soya-bean meal (48\% protein) was approximately twofold higher than that reported by NRC (1988) and McDowell (1989) but represented approximately one third of the concentration listed by INRA (1984) and by AEC (1987). For rapeseed the sources of information are limited. The present values were approximately $60 \%$ lower than those reported by Clandinin et al. (1981) and NRC (1988).

The variations due to the analytical methodology used for pteroylglutamate determination may account for some of the differences observed. The determination of total pteroylglutamates in feedstuffs is done usually by microbiological assay. In this case a 
Table 3. Analytical concentration of pteroylglutamates $(\mathrm{mg} / \mathrm{kg})$ in the different sources of pteroylglutamic acid, and the total concentration of pteroylglutamates in each of the semipurified diets containing the chemically pure pteroylmonoglutamic acid (standard curve) or the different feedstuffs

(Mean values with their standard errors)

\begin{tabular}{|c|c|c|c|c|}
\hline \multirow[b]{2}{*}{ Test meal } & \multicolumn{2}{|c|}{$\begin{array}{c}\text { Concentration of } \\
\text { pteroylglutamates in the } \\
\text { pteroylglutamic acid sources } \\
(\mathrm{mg} / \mathrm{kg})\end{array}$} & \multicolumn{2}{|c|}{$\begin{array}{c}\text { Concentration of } \\
\text { pteroylglutamates in the } \\
\text { semi-purified } \text { diet* }^{*}(\mathrm{mg} / \mathrm{kg})\end{array}$} \\
\hline & Mean & $\mathrm{SE}$ & Mean & SE \\
\hline \multicolumn{5}{|c|}{$\begin{array}{l}\text { Standard curve } \\
\text { (addition of } \\
\text { pteroylmonoglutamic acid, } \\
\text { mg/kg semi-purified diet) }\end{array}$} \\
\hline No addition & & & $0.06 \dagger$ & 0.00 \\
\hline 0.05 & $0 \cdot 24$ & 0.07 & $0 \cdot 13$ & $0-01$ \\
\hline $0 \cdot 10$ & $0 \cdot 37$ & 0.02 & $0 \cdot 19$ & 0.01 \\
\hline $0 \cdot 15$ & 0.62 & 0.04 & 0.21 & 0.02 \\
\hline $0 \cdot 20$ & 0.70 & 0.08 & 0.29 & 0.02 \\
\hline 0.40 & 0.96 & 0.05 & 0.37 & 0.04 \\
\hline \multicolumn{5}{|c|}{$\begin{array}{l}\text { Feedstuffs } \ddagger \\
\text { (dietary protein source) }\end{array}$} \\
\hline Soya-bean meal & $1 \cdot 36$ & 0.06 & $0 \cdot 32$ & 0.02 \\
\hline Rapeseed meal & 0.88 & 0.02 & 0.27 & 0.01 \\
\hline \multicolumn{5}{|c|}{$\begin{array}{l}\text { Feedstuffs } \ddagger \\
\text { (dietary energy source) }\end{array}$} \\
\hline Maize & 0.33 & 0.01 & 0.13 & 0.01 \\
\hline Barley & 0.26 & 0.01 & $0 \cdot 10$ & 0.01 \\
\hline Wheat & 0.25 & 0.01 & 0.08 & 0.01 \\
\hline \multicolumn{5}{|c|}{ Dietary vitamin source } \\
\hline Vitamin premix§ & 207 & 19 & 0.76 & $0 \cdot 10$ \\
\hline
\end{tabular}

* Gross energy and crude protein $(\mathrm{N} \times 6.25)$ values for the semi-purified diet were 15.26 (SE 0.14$) \mathrm{MJ} / \mathrm{kg}$ and $13 \cdot 3$ (SE $0 \cdot 2) \%$ respectively.

$\uparrow$ Value corresponds to the concentration of pteroylglutamic acid provided by the maize starch.

\$ The gross energy $(\mathrm{MJ} / \mathrm{kg}$ ) and crude protein (\%) contents of the feedstuffs were; soya-bean meal, 17.19 and 47.09; rapeseed meal, 17.45 and 38.8 ; maize, 16.73 and 10.5 ; barley, 16.34 and $12 \cdot 7$; wheat, 16.91 and $13 \cdot 3$ respectively.

$\S$ The first value corresponds to the concentration $\left(\mathrm{mg} / \mathrm{kg}\right.$ ) in the pure premix (Optiblend vitamin ${ }^{\infty}$, Hoffman-La Roche Canada Ltd, Mississauga, Ontario, Canada). For the second value, $250 \mathrm{~g}$ maize starch was replaced by $250 \mathrm{~g}$ maize starch supplemented with $5 \mathrm{~g}$ premix $/ \mathrm{kg}$.

hydrolysis with a conjugase is necessary before the assay in order to cleave the PteGlu $\mathrm{u}_{\mathrm{x}}$ to PteGlu $_{1}$, because PteGlu is the only form detectable by the micro-organism. The addition of amylase (EC 3.2.1 1 1 Cerna \& Kas, 1983) and, more recently, a proteolytic enzyme (De Souza \& Eitenmiller, 1990; Martin et al. 1990) for this hydrolysis were also suggested for human foods but the results are variable depending on the type of food evaluated (De Souza \& Eitenmiller, 1990). The absence of the conjugase pretreatment or its efficiency when it is used may explain some of the discrepancies among the different sources of information used in Table 4. In the present experiment the use of chicken pancreas conjugase or $\alpha$-amylase was omitted because it did not influence the amount of pteroylglutamate detected by the radioassay in pig diets (Matte \& Girard, unpublished results), a result which agrees with previous observations (Rothenberg et al. 1974; Schreiber \& Waxman, 1974) on the versatility of this assay for both forms of pteroylglutamate. A 
Table 4. Analytical concentrations of pteroylglutamic acid $(\mathrm{mg} / \mathrm{kg})$ in the different feedstuffs used in the present experiment and their corresponding theoretical values according to the source of information

\begin{tabular}{|c|c|c|c|c|c|c|c|}
\hline Ingredient & $\begin{array}{l}\text { Present } \\
\text { values }\end{array}$ & $\begin{array}{c}\text { Aitken \& } \\
\text { Hankin (1970) }\end{array}$ & $\begin{array}{c}\text { Clandinin et al. } \\
\text { (1981) }\end{array}$ & $\begin{array}{l}\text { INRA } \\
\text { (1984) }\end{array}$ & $\begin{array}{l}\text { AEC } \\
(1987)\end{array}$ & $\begin{array}{l}\text { NRC } \\
(1988)\end{array}$ & $\begin{array}{c}\text { McDowell } \\
\text { (1989) }\end{array}$ \\
\hline $\begin{array}{l}\text { Soya-bean meal } \\
(48 \%)\end{array}$ & 1.36 & - & $1 \cdot 30$ & 3.60 & 3.50 & 0.70 & 0.70 \\
\hline Rapeseed meal & 0.88 & - & $2 \cdot 30$ & - & - & $2 \cdot 30$ & - \\
\hline Maize & 0.33 & $0.26-0.27$ & - & 0.30 & 0.30 & 0.30 & 0.30 \\
\hline Barley & 0.26 & $0.45-0.67$ & - & 0.40 & 0.40 & 0.60 & 0.60 \\
\hline Wheat & 0.25 & $0.37-0.56$ & - & 0.30 & $0 \cdot 40$ & 0.50 & $0 \cdot 40$ \\
\hline Theoretical diet* & 0.54 & - & - & $1 \cdot 10$ & 1.09 & 0.40 & 0.39 \\
\hline
\end{tabular}

INRA, Institut National de la Recherche Agronomique; AEC, Alimentation Équilibrée Commentry; NRC, National Research Council.

* Contains $(\mathrm{g} / \mathrm{kg})$ : wheat 150 , maize 500 and soya-bean meal 250 , as sources of pteroylglutamates.

possibility remained, however, that the use of peptidase $(E C)$, which has not been tested yet in our laboratory, could release more pteroylglutamates detectable subsequently by the radioassay. Nevertheless, it is unlikely that the present results underestimated the total amount of pteroylglutamates compared with values in Table 4. Indeed, taking into account the chronology between the reported effect of peptidase and the references listed in this table, the peptidase was probably not used in any of the cases.

The conjugase treatment per se may also be a cause of variation in the determination of feedstuff pteroylglutamates. Indeed, it is known that conjugase is contaminated with a large amount of pteroylglutamates. It has to be treated and checked before its utilization for complete removal of endogenous pteroylglutamates. The absence of such conjugase treatment or its efficiency when it is used may also explain some of the differences observed in Table 4.

In spite of these analytical concerns it cannot be ruled out that some of these differences are partly due to the feedstuff itself (e.g. origin, species). The discrepancies reported among the different sources of information are critical because they can change considerably the total calculated content of pteroylglutamic acid in a given diet (Table 4) and its ability to meet the animal's requirements. Therefore, the calculated basal level of a complete diet is not a reliable measure on which to make a decision about the pertinency of incorporating pteroylglutamic acid into the vitamin premix. More research is needed, on the one hand, to evaluate better the importance of the analytical methodology and, on the other hand, to generate data on different origins of a given feedstuff in order to obtain average reliable values of their pteroylglutamate content.

\section{Bioavailability assays}

Whatever the level of pure pteroylmonoglutamic acid in the semi-purified diet or the age of the pigs, there was no difference $(P=0 \cdot 11)$ between the pre- and the postprandial concentrations of serum pteroylglutamate up to $5 \mathrm{~h}$ after the meal (Fig. 1). However, the values at $7 \mathrm{~h}$ after the meal tended to be lower $(P=0.08)$ or were lower $(P=0.02)$ than the preprandial concentrations of serum pteroylglutamate, at 10 and 16 weeks of age respectively. Since the postprandial concentrations of serum pteroylglutamate tended to decrease, an attempt was made to calculate the AUC from a baseline between the preprandial values and the last postprandial value of serum pteroylglutamate. In spite of that last correction and whatever the age of pigs, there was no relationship $(P=0.66)$ 

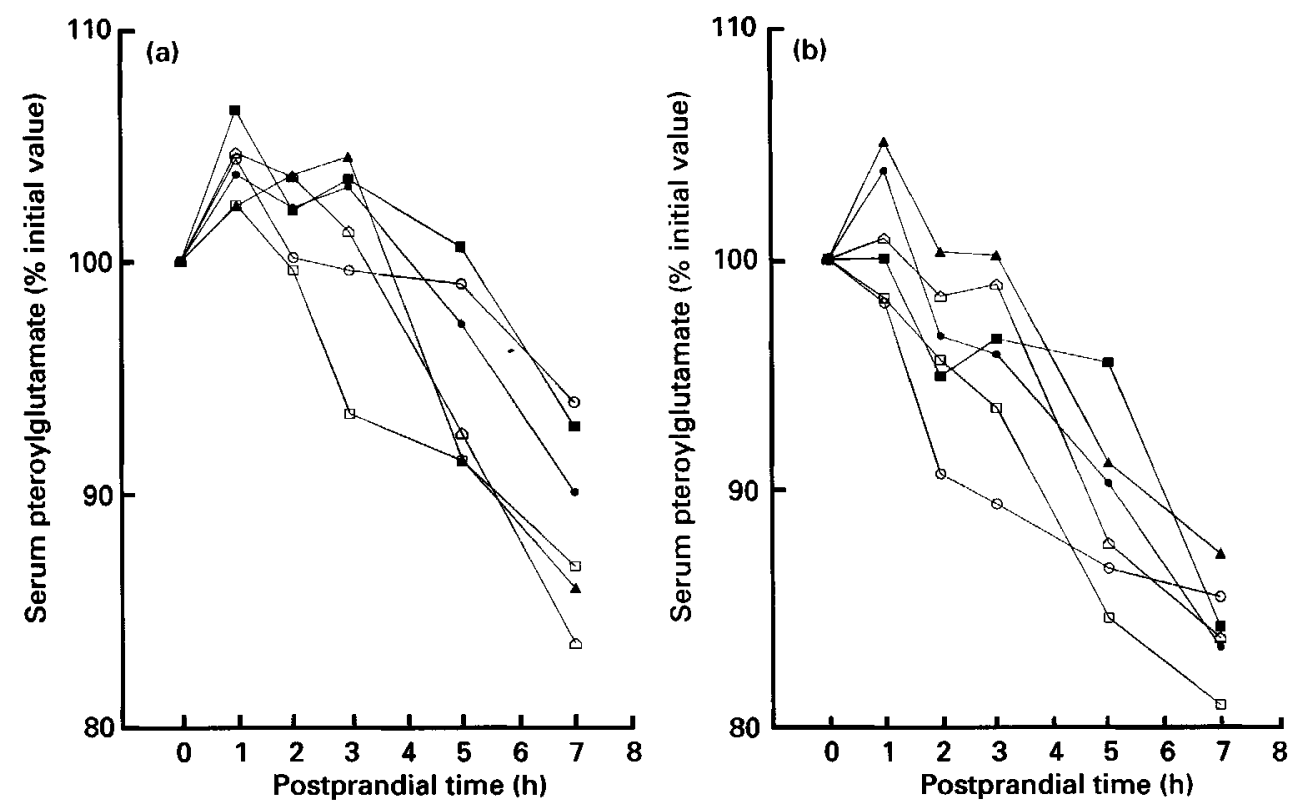

Fig. 1. Postprandial variations in serum pteroylglutamate (expressed as a percentage of the initial value) in pigs aged (a) 10 or (b) 16 weeks, following ingestion of a semi-purified diet containing chemically pure

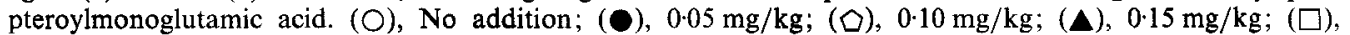
$0.20 \mathrm{mg} / \mathrm{kg} ;(\mathbf{W}), 0.40 \mathrm{mg} / \mathrm{kg}$. For details of diets and procedures, see Tables 1 and 2 and pp. 912-915.

between AUC and the level of chemically pure pteroylmonoglutamic acid added to the semi-purified diet.

In humans it is known that a fasting period of $24 \mathrm{~h}$ induces an elevation of the serum pteroylglutamate concentration which thereafter decreases after a meal (Hages et al. 1987; Remer et al. 1990). These variations are related to the depressed bile secretion which occurs after fasting. The amount of systemic pteroylglutamate directed towards this pool is decreased, leaving more pteroylglutamates in circulation. After feeding, the reactivation of bile secretion induces the opposite phenomenon (Remer et al. 1990).

If the same metabolism occurs in pigs, the delay between meals in the present experiment could have induced a fasting state which was sufficient to induce variations in bile secretion and consequently variations of serum pteroylglutamate. It is known that bile secretion is increased after a meal in pigs fed on conventional diets, but variations almost disappeared after consumption of a semi-purified diet (Juste et al. 1979). It seems that the present semipurified diet and feeding schedule might have influenced bile secretion sufficiently to increase the preprandial concentrations of serum pteroylglutamate. The postprandial decrease of serum pteroylglutamate which was particularly marked at 5 and $7 \mathrm{~h}$ postfeeding is unlikely to be the result of a postprandial tissue uptake since these animals received intramuscular injections at a level which is known to be sufficient (Matte et al. 1990) to maximize the concentrations of pteroylglutamates in serum. Similar variations of serum pteroylglutamate were also reported in gilts fed once daily on conventional diets supplemented with $0-4 \mathrm{mg}$ pteroylglutamic acid $/ \mathrm{kg}$ (Harper et al. 1991); serum pteroylglutamates decreased below prefeeding values beyond $12 \mathrm{~h}$ postfeeding. Therefore, in the present experiment it is possible that the fasting effect has a more important influence on concentration of serum pteroylglutamate than the amount of pteroylmonoglutamic acid absorbed from the semi-purified diet. In fact, the level of dietary pteroylglutamic acid was 
probably lower than the limit of detection of the method used. Such a phenomenon might explain the absence of a relationship between variation of postprandial serum pteroylglutamates and the level of pure pteroylmonoglutamic acid in the semi-purified diet. Nevertheless, these results do not invalidate the use of serum pteroylglutamate as an index of pteroylglutamate status in pigs in other circumstances since the conditions of the present experiment were particular (low level of dietary pteroylglutamic acid and intramuscular injections of pteroylmonoglutamic acid to saturate the pteroylglutamate status).

Although the lack of relationship between postprandial concentration of serum pteroylglutamate and increased levels of dietary pure pteroylmonoglutamic acid makes a quantitative evaluation of bioavailability in feedstuffs impossible with the present method, it can give original information on some aspects of pteroylglutamate absorption in pigs.

At 10 weeks of age, with most of the feedstuffs used, the postprandial concentrations of serum pteroylglutamate (Fig. 2) were not different $(P=0.21)$ from their corresponding preprandial values except for wheat. This absence of effect at 5 and $7 \mathrm{~h}$ after the meal seems to indicate that the postprandial decline of serum pteroylglutamate was delayed compared with that observed after ingestion of pure sources of pteroylmonoglutamic acid. It is possible that the form of dietary pteroylglutamates, which is PteGlu in pure sources and a mix of PteGlu $_{1}$ and PteGlu $\mathrm{u}_{\mathrm{x}}$ in feedstuffs, was involved in this effect. Indeed, although the reports disagree about the overall percentage of absorption, it is known that PteGlu $\mathrm{u}_{1}$ is absorbed more rapidly than the $\mathrm{PteGlu}_{\mathrm{x}}$ (Halsted, 1979; Gregory et al. 1991). At 16 weeks of age the difference in the postprandial variations of serum pteroylglutamate between pure sources of pteroylmonoglutamic acid and the feedstuffs was not clear. As was the case for the pure sources of pteroylmonoglutamic acid, postprandial values tended to be lower $(P<0.06)$ at 5 and $7 \mathrm{~h}$ after the meal in 16-week-old pigs. Such an apparent age effect suggests that either the hydrolysis of PteGlu $\mathrm{P}_{\mathrm{x}}$ to PteGlu $\mathrm{P}_{1}$ is more efficient and/or faster in older pigs or the capacity of absorption of PteGlu $\mathbf{u}_{1}$ is limited and saturated by the amount of PteGlu (originally free or after intestinal hydrolysis) available for the enterocytes. To the best of our knowledge, such information is not available in pigs, but it is known that in rats the capacity of the intestinal transport carrier system is reduced along with the maturation of the intestine (Said et al. 1986). Moreover, in humans the digestion and absorption of pteroylmonoglutamic acid also decreases with age (Shojania \& Hornady, 1970; Rosenberg \& Bowman, 1984).

The AUC values, established as previously mentioned for sources of dietary pure pteroylmonoglutamic acid, were different among feedstuffs $(P<0.001)$. Although there were some variations according to the age of pigs, the AUC values observed with wheat and barley were always the highest. This last result is rather surprising since the dietary amounts of pteroylmonoglutamic acid provided by these semi-purified diets were among the lowest of all the feedstuffs used. Two hypotheses might explain these results. The first one would attribute a value of $100 \%$ bioavailability to the wheat incorporated in the semi-purified diet. However, such an explanation is rather unlikely since this would mean that the other feedstuffs and the pure sources of pteroylmonoglutamic acid would have a relatively negligible level of bioavailability. The second hypothesis would be related to the previous hypothesis on the effect of fasting on bile secretion. The wheat, and to a lesser extent the barley, could have prevented the enhancement of the bile secretion which occurred after a postfasting meal. Although the information about bile secretion after ingestion of specific ingredients in the pig is limited, it is known that bile secretions are influenced by some ingredients such as wheat bran (Payne et al. 1989) and animal fat (Juste et al. 1983) or by the type of diet (semi-purified $v$. cereal-based; Juste, 1982).

In conclusion, the results of the present experiment indicate that further research on analytical procedure is needed in order to provide a reliable method for measuring 

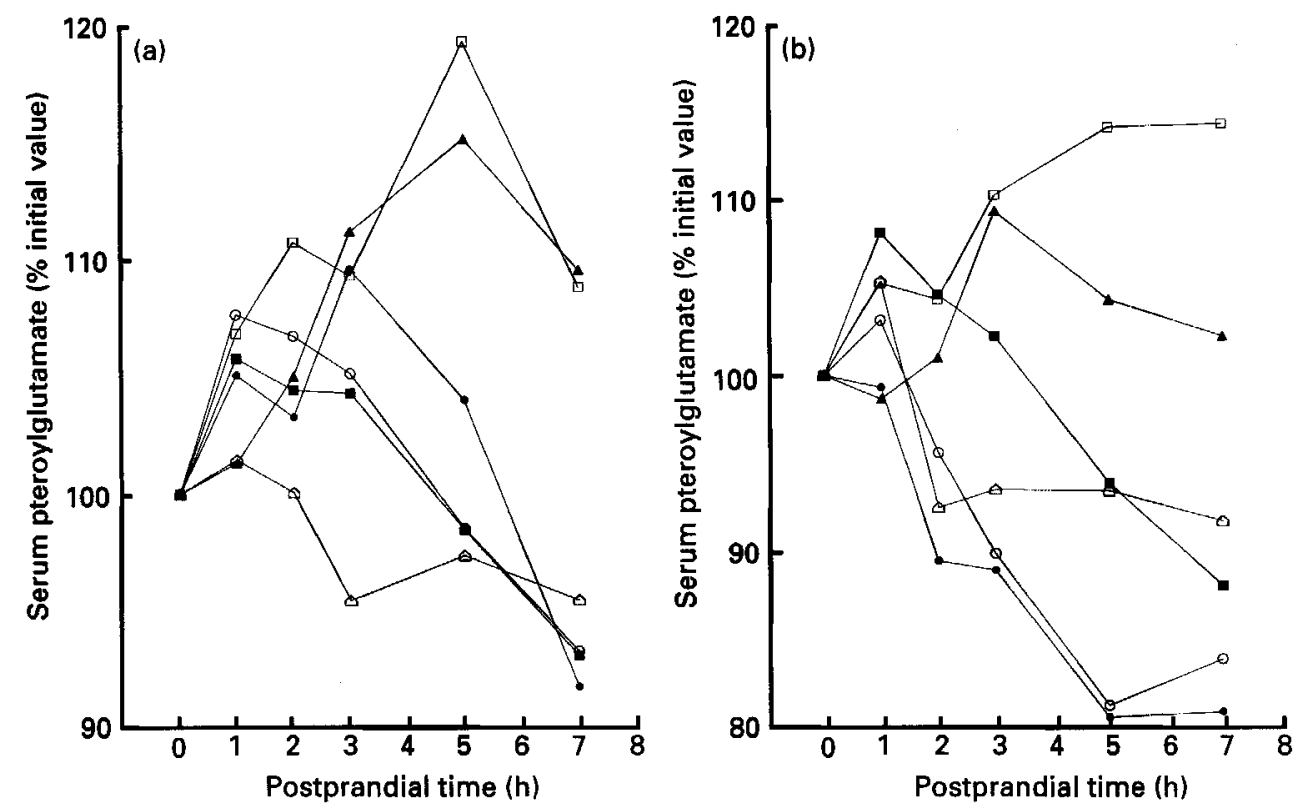

Fig. 2. Postprandial variations in serum pteroylglutamate (expressed as a percentage of the initial value) in pigs aged (a) 10 or (b) 16 weeks, following ingestion of a semi-purified diet containing various feedstuffs as sources of pteroylglutamic acid. (O), Soya-bean meal, $48 \%$; (O), rapeseed meal; (O), maize; (A), barley; ( $\square$ ), wheat; ( $\square$ ), vitamin premix. For details of diets and procedures, see Tables 1 and 2 and pp. 912-915.

concentrations of pteroylglutamic acid in different sources of a given feedstuff used in pig feeding. In addition to this analytical concern, the measurement of the proportion of bioavailable pteroylglutamic acid in feedstuffs for pigs using postprandial variations of serum pteroylglutamates appears to be technically hazardous, according to the apparent importance of feeding frequency. In this case an evaluation of the proportion of pteroylglutamic acid provided by bile secretion and excretion is essential for an accurate measurement of bioavailable pteroylglutamic acid in feedstuffs used in pig feeding.

The authors are grateful to Michelle Guillette and Chrystiane Plante for technical assistance, Marcel Morrissette, Mariette Vanier, Dominique Morrissette, and Irène Bergeron for animal care, and Anick Bérard and Dany Marois for statistical analysis. Special thanks are addressed to Mme Catherine Juste, INRA, Jouy-en-Josas, France, for her pertinent advice in the preparation of the manuscript. This work was partly subsidized by HoffmanLaRoche Ltd, Basel, Switzerland and Mississauga, Ontario, Canada.

\section{REFERENCES}

Agriculture Canada (1984). Recommended Code of Practice for Care and Handling of Pigs. Publication no. $1771 \mathrm{E}$. Ottawa: Agriculture Canada.

Aitken, F. C. \& Hankin, R. G. (1970). Vitamins in Feeds for Livestock. Commonwealth Bureau of Animal Nutrition, Technical Publication no. 25. Farnham Royal: Commonwealth Agricultural Bureaux.

Alimentation Équilibrée Commentry (1987). Recommandations pour la Nutrition Animale, 5th ed. Anthony, France: Rhône-Poulenc Animal Nutrition.

Babu, S. \& Lakshmaiah, N. (1987). Availability of food folates by liver folate repletion in rats. Nutrition Reports International 35, 831-836.

Buffington, C. A., Chandler, C. J. \& Halsted, C. H. (1987). Folate hydrolysis and absorption in pig small intestine. Clinical Research 35, 768A. 
Cerna, J. \& Kas, J. (1983). New conception of folacin assay in starch or glycogen containing food samples. Nahrung 27, 957-964.

Chandler, C. J., Wang, T. T. Y. \& Halsted, C. H. (1986). Brush border pteroylglutamate hydrolase in pig jejunum. In Chemistry and Biology of Pteridines. Pteridines and Folic Acid Derivatives, pp. 539-542 [B. A. Cooper and V. M. Whitehead, editors]. Berlin: Walter de Gruyter.

Clandinin, D. R., Roblee, A. R., Slinger, S. J. \& Bell, J. M. (1981). Composition of canola meal. In Canola Meal for Livestock and Poultry. Publication no. 59, pp. 8-11 [D. R. Clandinin, editor]. Winnipeg: Canola Council of Canada.

Clifford, A. J., Bills, N. D., Peerson, J. M., Muller, H. G., Burk, G. E. \& Rich, K. D. A. (1993). Depletionrepletion folate bioassay based on growth and tissue folate concentrations of rats. Journal of Nutrition 123 , 926-932.

De Souza, S. \& Eitenmiller, R. (1990). Effects of different enzyme treatments on extraction of total folate from various foods prior to microbiological assay and radioassay. Journal of Micronutrient Analysis 7, 37-57.

Farrar, G. \& Blair, J. A. (1989). Folate bioavailability. In Nutrient Availability: Chemical and Biological Aspects, pp. 356-361 [D. A. T. Southgate, I. T. Johnson and G. R. Fenwick, editors]. Cambridge: Royal Society of Chemistry.

Farrar, G., Stankiewicz, M. J. \& Blair, J. A. (1989). Intestinal speciation and bioavailability of folic acid. Biology Chemistry Hoppe Seyler 370, 380-381.

Friendship, R. M. \& Wilson, M. R. (1991). Effects of intramuscular injections of folic acid in sows on subsequent litter size. Canadian Veterinary Journal 32, 565-566.

Gee, J. M., Bhabuta, A. \& Johnson, I. T. $(1989 a)$. Use of the rat for measuring the biological availability of folates in food. In Nutrient Availability: Chemical and Biological Aspects, pp. 362-364 [D. A. T. Southgate, I. T. Johnson $\&$ G. R. Fenwich, editors]. Cambridge: Royal Society of Chemistry.

Gee, J. M., Bhabuta, A. \& Johnson, I. T. $(1989 b)$. A technique for assessing the biological availability of folate in foods. Food Chemistry 31, 149-158.

Gregory, J. F., Bhandari, S. D., Bailey, L. B., Toth, J. P., Baumgartner, T. G. \& Cerda, J. J. (1991). Bioavailability of deuterium-labelled monoglutamyl forms of folic acid and tetrahydrofolates in human subjects. FASEB Journal 5, A915.

Hages, M., Mirgel, C. \& Pietrzik, K. (1987). Changes in serum levels of folic acid during fasting. In Symposium: Vitamine und Ergotropika und Podiumsdiskussion zur Verzchrsregulation, pp. 215-218. [G. Jallen and S. Wille, editors]. Jena: Karl Marx Universität, Sektion Tier produktion Veterinärmedizin.

Halsted, C. H. (1979). The intestinal absorption of folates. American Journal of Clinical Nutrition 32, 846-855.

Halsted, C. H. (1989). The intestinal absorption of dietary folates in health and disease. Journal of the American College of Nutrition 8, 650-658.

Harper, A. F., Lindemann, M. D. \& Kornegay, E. T. (1991). Diurnal serum folates profile of gilts fed a single meal containing varying levels of supplemental folic acid. Journal of Animal Science 69, Suppl. 1, 361.

Hoppner, K. \& Lampi, B. (1986). Effect of aspirin ingestion on folate bioavailability evaluated by rat liver bioassay. In Chemistry and Biology of Pteridines. Pteridines and Folic Acid Derivatives, pp. $531-537$ [B. A. Cooper and V. M. Whitehead, editors]. Berlin: Walter de Gruyter.

Hoppner, K. \& Lampi, B. (1988). Antiacid ingestion and folate bioavailability in the rat. Nutrition Reports International 38, 539-546.

Institut National de la Recherche Agronomique (1984). Alimentation des Animaux Monogastriques: Porcs, Lapins, Volailles. Paris: Institut National de la Recherche Agronomique.

Juste, C. (1982). Apports endogènes par les sécrétions digestives chez le porc (Endogenous supplies from the digestive secretions in the pig). In Physiologie Digestive Chez le Porc, pp. 155-175 [J.-P. Laplace, T. Corring \& A. Rérat, editors]. Jouy-en-Josas: Institut National de la Recherche Agronomique.

Juste, C., Corring, T. \& Bréant, Ph. (1979). Excrétion biliaire chez le porc: niveau et réponse au repas (Biliary excretion in the pig: magnitude and response to meal intake). Annales de Biologie Animale, Biochimie, Biophysique 19, 79-90.

Juste, C., Demarne, Y. \& Corring, T. (1983). Response of bile flow, biliary lipids and bile acid pool in the pig to quantitative variations in dietary fat. Journal of Nutrition 113, 1691-1701.

Keagy, P. M. (1990). Animal assays for folate bioavailability-a critical evaluation. Folic Acid Metabolism in Health and Disease 13, 139-150.

Keagy, P. M., Shane, B. \& Oace, S. M. (1988). Folate bioavailability in humans: effects of wheat bran and beans. American Journal of Clinical Nutrition 47, 80-88.

Kovčin, S., Živković, S., Beuković, M. \& Lalić, M. (1988). Uticaj folne kiseline na reprodukciju krmača (Effect of folic acid on reproduction of sows), Zbornik Radova 17-18, 103-110.

Lavoie, A. \& Cooper, B. A. (1974). Rapid transfer of folic acid from blood to bile in man and its conversion into folate coenzymes and into a pteroylglutamate with little biological activity. Clinical Science and Molecular Medicine 46, 729-741.

Lindemann, M. D. \& Kornegay, E. T. (1986). Folic acid additions to weanling pig diets. Journal of Animal Science 63,35 .

Lindemann, M. D. \& Kornegay, E. T. (1989). Folic acid supplementation to diets of gestating lactating swine over multiple parities. Joumal of Animal Science 67, 459-464. 
McDowell, L. R. (1989). Vitamins in Animal Nutrition. San Diego: Academic Press Inc.

Martin, J. I., Landen, W. O. Jr, Soliman, A.-G. M. \& Eitenmiller, R. R. (1990). Application of a tri-enzyme extraction for total folate determination in foods. Journal of the Association of Official Analytical Chemists 73 , 805-808.

Mason, J. B. (1990). Intestinal transport of monoglutamyl folates in mammalian systems. Folic Acid Metabolism in Health and Disease 13, 47-63.

Matte, J. J. \& Girard, C. L. (1989). Effects of intramuscular injections of folic acid during lactation on folates in serum and milk and performances of sows and piglets. Journal of Animal Science 67, 426-431.

Matte, J. J., Girard, C. L., Bilodeau, R. \& Robert, S. (1990). Effects of intramuscular injections of folic acid on serum folates, haematological status and growth performance of growing-finishing pigs. Reproduction Nutrition Développement 30, 103-114.

Matte, J. J., Girard, C. L. \& Brisson, G. J. (1984a). Serum folates during the reproductive cycle of sows. Journal of Animal Science 59, 158-163.

Matte, J. J., Girard, C. L. \& Brisson, G. J. (1984b). Folic acid and reproductive performances of sows. Journal of Animal Science 59, 1020-1025.

Matte, J. J., Girard, C. L. \& Brisson, G. J. (1992). The role of folic acid in the nutrition of gestating and lactating primiparous sows. Livestock Production Science 32, 131-148.

Mosenthin, R., Sauer, W. C. \& Volker, L. (1990). Influence of pectin on the digestibility of biotin in growing pigs. Agribiological Research-Zeitschrift für Agrarbiologie Agrikulturechemie Ökologie 43, $175-181$.

National Research Council (1988). Nutrient Requirements of Swine, 9th ed. Washington, DC: National Academy Press.

Payne, D., Juste, C., Corring, T. \& Février, C. (1989). Effects of wheat bran on bile secretion in the pig. Nutrition Reports International 40, 761-771.

Perry, J. \& Chanarin, I. (1968). Absorption and utilization of polyglutamyl forms of folate in man. British Medical Journal 4, 546-549.

Remer, T., Hages, M. \& Pietrzik, K. (1990). Alterations in blood folate concentrations during short-term fasting. Recent Knowledge on Iron and Folate Deficiencies in the World 197, 393-402.

Rosenberg, I. H. \& Bowman, B. B. (1984). Gastrointestinal function and aging. In The Role of the Gastrointestinal Tract in Nutrient Delivery, pp. 259-274 [M. Green and H. L. Greene, editors]. Orlando: Academic Press.

Rothenberg, S. P., daCosta, M., Lawson, J. \& Rosenberg, Z. (1974). The determination of erythrocytes folate concentration using a two-phase ligand-binding radioassay. Blood 43, 437-443.

Said, H. M., Ghishan, F. K. \& Redha, R. (1986). Folate transport by human intestinal brush border membrane vesicles. Gastroenterology $90,1612$.

Schreiber, C. \& Waxman, S. (1974). Measurements of red cell folate levels by ${ }^{3} \mathrm{H}-$ pteroylglutamic acid ( ${ }^{3} \mathrm{H}-\mathrm{Pte}-$ Glu) radioassay. British Journal of Haematology 27, 551-558.

Shojania, A. M. \& Hornady, G. (1970). Folate metabolism in newborns and during early infancy. I. Absorption of pteroylglutamic (folic) acid in newborns. Pediatric Research 4, 412-421.

Statistical Analysis Systems (1990). SAS User's Guide: Statistics, Version 6, 4th ed. vol. 2. Cary, North Carolina: SAS Institute Inc.

Swiatlo, N., O'Connor, D. L., Andrews, J. \& Picciano, M. F. (1990). Relative folate bioavailability from diets containing human, bovine and goat milk. Journal of Nutrition 120, 172-177.

Thaler, R. C., Nelssen, J. L., Goodband, R. D. \& Allee, G. L. (1989). Effect of dietary folic acid supplementation on sow performance through two parities. Journal of Animal Science 67, 3360-3369.

Tremblay, G. F., Matte, J. J., Lemieux, L. \& Brisson, G. J. (1986). Serum folates in gestating swine after folic acid addition to diet. Journal of Animal Science 63, 1173-1178.

Zheng, L. L., Lin, Y., Lin, S. \& Cossins, E. A. (1992). The polyglutamate nature of plant folates. Phytochemistry 31, 2277-2282. 